\title{
Social and health-related predictors of family function in older spousal caregivers: a cross-sectional study
}

\author{
Sofia Cristina lost Pavarinii, ${ }^{1 \odot}$, Allan Gustavo Bregola ${ }^{3 \oplus}$, Bruna Moretti Luchesi ${ }^{4 \oplus}$, Déborah Oliveira ${ }^{5 \odot}$, \\ Fabiana de Souza Orlandi ${ }^{2},{ }^{\circ}$, Fernanda Gomez de Moura ${ }^{6}{ }^{\odot}$, Helena Rita Oliveira Silva ${ }^{7}$, Nathalia Alves de Oliveira ${ }^{2}{ }^{\circ}$, \\ Marisa Silvana Zazzetta ${ }^{1,2}$, Ariene Angelini dos Santos-Orlandi1,8๑ , Ana Carolina Ottaviani2 ${ }^{\odot}$
}

\begin{abstract}
Given the benefits of adequate family function for the health and well-being of older adults, it is important to understand what factors predict adequate family function in older people who care for their spouses. Objective: Analyse predictors of family function in older spousal caregivers. Methods: A cross-sectional study design was used to investigate a non-probabilistic sample of 298 older spousal caregivers. Home-based face-to-face interviews were used to evaluate sociodemographic variables and care context, family function (Family APGAR), cognitive function, perceived stress, and depressive symptoms. Data were analysed using multiple logistic regression with stepwise forward method for variable section. Results: Older caregivers having some degree of cognitive impairment $(\mathrm{OR}=-0.160,95 \% \mathrm{Cl} 0.444-0.579)$, depressive symptoms $(\mathrm{OR}=-0.848,95 \% \mathrm{Cl} 0.726-0.992)$ or high levels of stress (OR $=-0.955,95 \% \mathrm{Cl} 0.914-0.999)$ had overall lower levels of family function. Having more children was linked to approximately 1.3 times higher family function (95\% $\mathrm{Cl} 1.080-1.057)$. Conclusion: Stress, depression, cognitive decline, and number of children are predictors of family function and should be considered in social and health care strategies within the family caregiving context.
\end{abstract}

Keywords: caregivers, aged, family relations, cognitive dysfunction, depression, emotional stress.

VARIÁVEIS SOCIAIS E DE SAÚDE PREDITORAS DA FUNÇÃO FAMILIAR EM CUIDADORES CÔNJUGES IDOSOS: UM ESTUDO TRANSVERSAL

RESUMO. Dados os benefícios da função familiar adequada para a saúde e o bem-estar de pessoas idosas, é importante compreender quais fatores predizem o funcionamento familiar adequado em pessoas idosas que cuidam de seus cônjuges. Objetivo: Analisar preditores de funcionamento familiar em idosos cuidadores de cônjuges idosos. Métodos: Um estudo transversal foi usado para investigar uma amostra não probabilística de 298 cuidadores cônjuges idosos. Foram realizadas entrevistas domiciliares para avaliar variáveis sociodemográficas e situação de cuidado, funcionamento familiar (APGAR familiar), função cognitiva, percepção de estresse e sintomas depressivos. Os dados coletados foram analisados por meio de regressão logística múltipla com método stepwise forward para seleção das variáveis. Resultados: Idosos cuidadores com algum grau de comprometimento cognitivo $(\mathrm{OR}=-0,160, \mathrm{IC95} \% 0,444-0,579)$, sintomas depressivos ( $\mathrm{OR}=-0,848$, IC95\% 0,726-0,992) ou altos níveis de estresse ( $\mathrm{OR}=-0,955, \mathrm{IC} 95 \%$ 0,914-0,999) tiveram menores níveis de funcionamento familiar. Ter mais filhos esteve relacionado a maiores níveis de funcionamento familiar em aproximadamente 1,3 vez (IC95\% 1,080-1,057). Conclusão: A presença de estresse, depressão, declínio cognitivo e número de filhos são preditores do funcionamento familiar e devem ser considerados como parte de estratégias sociais e de saúde no contexto de cuidado familiar.

Palavras-chave: cuidadores, idosos, relações familiares, disfunção cognitiva, depressão, estresse emocional.

This study was conducted at the Department of Gerontology, Universidade Federal de São Carlos, São Carlos, SP, Brazil.

'Department of Gerontology, Universidade Federal de São Carlos - São Carlos, SP, Brazil.

${ }^{2}$ Graduate Program in Nursing, Universidade Federal de São Carlos - São Carlos, SP, Brazil.

${ }^{3}$ School of Health Sciences, University of East Anglia - Norwich, United Kingdom.

${ }^{4}$ Graduate Program in Nursing, Universidade Federal de Mato Grosso do Sul - Três Lagoas, MS, Brazil.

${ }^{5}$ School of Medicine, Department of Psychiatry, Universidade Federal de São Paulo - São Paulo, SP, Brazil.

EUniversidade do Vale do Parába, Graduate Program in Gerontology - São José dos Campos, SP, Brazil.

PPrivate Practice - São Joaquim da Barra, SP, Brazil.

${ }^{8}$ Department of Nursing, Universidade Federal de São Calos - São Carlos, SP, Brazil.

Ana Carolina Ottaviani. Nursing Post-Graduation Program, Universidade Federal de São Calos (UFSCar). Rodovia Washington Luís Km 235 - $13565-905$ São Carlos SP - Brazil. E-mail: carol.ottaviani@gmail.com

Disclosure: The authors report no conflicts of interest.

Funding: Conselho Nacional de Desenvolvimento Científico e Tecnológico (CNPq) [Grant No. 304068/2015-6] and Fundação de Amparo à Pesquisa do Estado de São Paulo (Grant No. 2017/04129-9).

Received on April 03, 2020. Accepted in final form on September 08, 2020.

\section{(c) BY}




\section{INTRODUCTION}

The increase in life expectancy of the population combined with the high prevalence of chronic diseases is related to an increase in functional capacity limitations in the older adults. ${ }^{1}$ These limitations require long-term care, which mostly come from the family and informal context. ${ }^{1,2}$ Current family arrangements offer intergenerational support and provide the opportunity for older couples to live together longer. ${ }^{3}$ In such cases, it is common for older individuals to become responsible for the care provision of their dependent older spouses, especially older women.

Family functionality is described as the dynamics of family relationships that are formed within families throughout their history, ${ }^{4}$ with adaptation, companionship, affection and ability to resolve the family with its members. ${ }^{5}$ Family function can potentially affect the social, emotional, and physical health of individuals. ${ }^{6}$ It reflects the family's ability to meet the essential life goals of its members and the way the family members interact with each other within the family unit. ${ }^{7}$ A family with adequate levels of family function is more likely to solve critical situations with emotional stability. Conflicts are often solved in a more balanced way, without overloading any family member, and individuals are able to adapt harmoniously in response to changes in life and stressful events. ${ }^{8}$

High demands for informal care, as well as changes in day-to-day routines and social roles, may lead to high levels of perceived burden and stress in family caregivers, ${ }^{9}$ which are associated with lower levels of perceived and received support, ${ }^{10}$ as well as poor family function. ${ }^{11}$ When the family struggles to adapt to the challenges arising from ageing and the presence of chronic diseases, family relationships may be affected negatively, impacting the physical, emotional, and psychological well-being of older adults. ${ }^{12,13}$

Considering a qualitative approach, studies indicate that when the impairment of functional capacity affects the elderly, the entire family system is also affected, regardless of social class ${ }^{14,15}$. Regarding the caregiver, the family support provided to the elderly can occur in an imposed way, without emotional/social support and information about the care to be provided. The lack of specific knowledge and preparation of families for the care causes negative changes in social support and family relationships ${ }^{15}$.

Previous meta-analyses have shown that lower levels of social support are associated with higher levels of perceived burden on family caregiver and with poorer cognitive performance in older adults, ${ }^{16}$. Older people may receive support from different sources, but family members are the major source ${ }^{17}$ Sustaining good quality family function helps maintain the health and well-being of those older people who provide care for dependent family members. ${ }^{2}$ Whilst being female and experiencing high family demands can cause high levels of strain, having fewer family demands, a stronger bond with family members, and having better education as well has been shown to be associated with better family function. ${ }^{18}$

A previous study with 2,052 Brazilian older adults demonstrated that poor cognitive function and higher dependence, as well as not having children, were predictors of low family function. However, living with someone else, as opposed to alone, was found to be an important predictor of adequate family function. The authors indicated that in old age, the lack of autonomy, dependence, dementia, and missing social support, affect the quality of life of the elderly. It is believed that the presence of family members increases the safety of the elderly, since they can assist in daily activities and also contribute to social development. ${ }^{19}$

The literature has shown a rapid increase in the number of older people involved with family caregiving worldwide, and it has been argued that more needs to be done to support these people. ${ }^{20,21}$ Previous meta-analysis has pointed out that spousal caregivers are more likely to be older, providing more hours of care a day and for many years, and are living in poorer physical health conditions when compared to younger, children, or in-law caregivers. ${ }^{22}$

Given the benefits of adequate family function for the health and well-being of older adults, it is important to understand whether sociodemographic aspects and the context of care, cognitive function, depressive symptoms and perceived stress predict adequate family function in older people who are caring for their spouse. These variables have not been evaluated in previous studies in this population. The current study aimed to identify some of the predictors of family function in older individuals providing care for their spouses. We anticipate that this will help researchers and clinicians plan and deliver effective family interventions aimed at better supporting these individuals in Brazil.

\section{METHODS}

This study used a cross-sectional exploratory design with a convenience sample. Participants were living in the city of São Carlos-SP, Brazil, and met the following inclusion criteria: 1 ) be aged $\geq 60 ; 2$ ) be registered at one of the primary health care services of Sao Carlos, SP; 3) be the primary caregiver for a spouse aged $\geq 60$ and dependent on care for at least one basic activity of 
daily living (BADL) or at least one instrumental activity of daily living (IADL) as assessed by the Katz Index ${ }^{23}$ and the Lawton and Brody Scale; ${ }^{24}$ and 4 ) be willing to provide informed consent. The exclusion criteria were: 1) both older spouses in the family were dependent for BADL and IADL; 2) older adults showed severe listening or visual impairments that compromised their ability to respond to the questionnaires; and 3) candidates had sufficient communication difficulties to prevent their understanding of the questions.

Participants were recruited via patient registries within each of the primary health care services in Sao Carlos, SP. A total of 594 families were initially identified, 26 were excluded because of death of one of the older partners, 28 because of change of address, and 69 for not being found at their address after three contact attempts. A total of 471 families were visited and 84 refused to take part in the study. The older couples had their functional capacity evaluated (BADL and IADL) and 36 were excluded for being both dependent on care. Of the 351 remaining potential participants, 53 were non-spousal caregivers and were excluded, totalling the final sample of 298 older spousal caregivers. Trained researchers collected informed consent forms and interviewed the participants at their home after a first contact. Each interview was carried out once and lasted approximately one hour and thirty minutes.

All ethical procedures for research with people were respected, following the 466/2012 National Brazilian Resolution, regimented by the National Health Council. The project was authorised by the city health council and was approved by the Research Ethics Committee at the Universidade Federal de São Carlos (416.467/2013). Data were collected after the participant read, understood, and provided informed consent. The researchers ensured that the individuals who were interested in taking part in the study met the inclusion criteria and were cognitively capable of providing consent.

\section{Measurement outcomes}

- Sociodemographic and care information: these data were collected using a questionnaire created by the research team and contained the following variables: gender (female/male), age (years), schooling (years), family income (in relation to national minimum wage), number of children (continuous), number of years of caregiving (years), amount of time caregiving per day (hours), material/financial and compassionate/emotional support received to care (yes/no), level of dependence of the person cared for (BADL - Katz Index ${ }^{23}$ and IADL — Lawton and Brody Scale). ${ }^{24}$
- Family function (Family APGAR): ${ }^{2}$ This is a commonly used tool to measure family function through the evaluation of individuals' satisfaction in relation to five areas: adaptation, partnership, growth, affection and resolution. It helps identify whether family function is adequate (13+ points), moderately dysfunctional (9-12 points) or highly dysfunctional (1-8 points). ${ }^{25,26}$ A previous integrative review investigating the use of Family APGAR scores to evaluate family relationships in older adults showed that this instrument is easy to use and interpret, allowing the detection of family dysfunction in older adults and their caregivers. ${ }^{27}$

- Cognitive function (Addenbrooke's Cognitive Examination Revised - ACE-R): ${ }^{28,29}$ this is a brief battery assessing five domains: orientation/ attention, memory, verbal fluency, language and visual-spatial skills. Total scores range from zero to 100 points, with the higher the scores, the better the cognitive performance, where the threshold for each domain is defined as follows: $<17$ points for orientation/attention, $<15$ points for memory, $<8$ points for verbal fluency, $<22$ points for language and $<13$ visual-spatial skills. For the purpose of data analysis, participants had their total scores divided into two groups, one below and the other above the median (median=64). The ACE-R were translated into Brazilian Portuguese and had good reliability and validity for the cut-off proposals. ${ }^{30}$

- Depressive symptoms (Geriatric Depression Scale - GDS-15): ${ }^{31,32}$ the total scale scores vary from zero to $15,0-5$ means absence of depressive symptoms, 6-10 means mild depressive symptoms, and 11-15 means severe depressive symptoms. The GDS-15 has been translated for use in Brazil and represents the classic assessment to evaluate mood in older people.

- Perceived stress (Perceived Stress Scale): $:^{33,34}$ this scale is composed of 14 items. The total scores result from the sum of all the responses and range from zero to 56 , and the higher the total score, the higher the perceived stress levels. PSS has been translated to Brazilian Portuguese and reports good internal consistency in its application in older people for the full version of the assessment $(\alpha=0.82){ }^{34}$

\section{Data analysis}

Data analysis was carried out in Statistical Package for the Social Sciences (SPSS ${ }^{\circledR}$ ), version 22. Basic descriptive statistics were calculated for all the studied variables (frequency, means, medians and standard deviations). Multiple logistic regression using a stepwise forward 
method for variable selection was used to identify the predictors of family dysfunction. ${ }^{35}$ The dependent variable was family function based on the Family APGAR scores ( 1 =poor family function or $2=$ adequate family function). The continuous independent variables were the following: number of children (continuous), perceived stress levels (total scores) and depressive symptoms (total scores). The caregivers' cognitive status was considered to be a dichotomous variable divided into two categories: $1=$ with cognitive impairment, 2 =without cognitive impairment, following the values above or below the median threshold. A threshold level of $\mathrm{p}<0.20$ was used for the variable section for the univariate analyses. To have a good performance of regression model, a criteria decision to variable selection was adopted with a threshold level of $p<0.20$ in univariate analyses. For the multivariate analysis, a threshold of $\mathrm{p}<0.05$ was used.

\section{RESULTS}

The 298 older spousal caregivers taking part in the study were mostly females $(78.2 \%)$, with a mean age of 69.9 ( \pm 6.9$)$ years old and most between 60 and 69 years old (54.4\%). The mean schooling degree was of $3.5( \pm 3.2)$ years and $63.1 \%$ had at least incomplete primary school. The mean number of children was 4.3 $( \pm 2.7)$ and $52.7 \%$ had 4 children or more. The mean family income was of $\mathrm{R} \$ 2,266.29$ (approximately $\$ 677.89$ USA dollars), with $55.0 \%$ reporting more than 3 minimum salary units (approximately $\$ 650.51$ USA dollars). With regard to the care provided, $43.3 \%$ reported being caregivers for more than five years, and the majority (62.4\%) provided up to five hours of care a day for their spouses. About $85 \%$ reported that they did not receive any material or financial help, and almost $54 \%$ indicated that they did not receive any compassionate/emotional support (Table 1 ).

With regard to family function, $85.6 \%(n=255)$ reported adequate family function, $7.4 \%(\mathrm{n}=22)$ moderate family function and $7.0 \%(\mathrm{n}=21)$ poor family function. The mean scores for the cognition measurement tool (ACE-R) was 62.9 ( \pm 18.4$)$ and the mean scores for each domain were as follows: attention/orientation $=13.5$ $( \pm 2.9)$, memory=14.6 $( \pm 6.2)$, verbal fluency=5.9 $( \pm 2.9)$, language $=18.3( \pm 5.6)$, and visual-spatial skills $=10.3$ ( \pm 3.6$)$. Approximately $50 \%$ all spousal caregivers scored lower than the expected overall median for the ACE-R. The majority of the sample $(77.8 \%, \mathrm{n}=228)$ did not have depressive symptoms and $19.1 \%(\mathrm{n}=56)$ had mild depressive symptoms, while $3.1 \%(\mathrm{n}=9)$ had severe symptoms. With regard to perceived stress levels, the mean was of $18.52( \pm 10.7)$ points (moderate to low).
Table 1. Sociodemographic and care information ( $n=298)$, São Carlos, SP, Brazil, 2014.

\begin{tabular}{|c|c|c|}
\hline & $\mathbf{n}$ & $\%$ \\
\hline \multicolumn{3}{|l|}{ Gender } \\
\hline Female & 233 & 78.2 \\
\hline Male & 65 & 21.8 \\
\hline \multicolumn{3}{|l|}{ Age (years) } \\
\hline $60-69$ & 162 & 54.4 \\
\hline $70-79$ & 100 & 33.5 \\
\hline$\geq 80$ & 36 & 12.1 \\
\hline \multicolumn{3}{|l|}{ Schooling (years) } \\
\hline None & 58 & 19.4 \\
\hline $1-4$ & 188 & 63.1 \\
\hline $5-8$ & 28 & 9.4 \\
\hline$\geq 9$ & 24 & 8.1 \\
\hline \multicolumn{3}{|c|}{ Family income (in Brazilian minimum salary units) ${ }^{*}$} \\
\hline Up to 1 minimum salary & 35 & 11.8 \\
\hline $2-3$ & 99 & 33.2 \\
\hline$>3$ & 164 & 55.0 \\
\hline \multicolumn{3}{|l|}{ Number of children } \\
\hline $0-3$ & 139 & 46.6 \\
\hline$\geq 4$ & 157 & 52.7 \\
\hline Information not provided & 2 & 0.7 \\
\hline \multicolumn{3}{|l|}{ Years of caregiving } \\
\hline$<1$ & 57 & 19.1 \\
\hline $1-5$ & 100 & 33.6 \\
\hline$>5$ & 129 & 43.3 \\
\hline Information not provided & 12 & 4.0 \\
\hline \multicolumn{3}{|l|}{ Hours per day caregiving } \\
\hline$\leq 5$ & 186 & 62.4 \\
\hline $6-9$ & 37 & 12.4 \\
\hline$\geq 10$ & 66 & 22.1 \\
\hline Information not provided & 9 & 3.1 \\
\hline \multicolumn{3}{|c|}{ Material/financial help received } \\
\hline No & 254 & 85.3 \\
\hline Yes & 43 & 14.4 \\
\hline Information not provided & 1 & 0.3 \\
\hline \multicolumn{3}{|c|}{ Compassionate/emotional support } \\
\hline No & 160 & 53.7 \\
\hline Yes & 136 & 45.6 \\
\hline Information not provided & 2 & 0.7 \\
\hline
\end{tabular}


Table 2 shows the results from the multiple logistic regression analysis. The results demonstrated that family function decreased approximately 0.95 for every point increase in the perceived stress scale. Similarly, having some degree of cognitive impairment ( $\mathrm{OR}=0.160$, 95\%CI $0.444-0.579$ ) or presence of depressive symptoms (OR=0.848, 95\%CI 0.726-0.992) also decreased family function to some degree. Having more children was shown to increase family function by approximately 1.3 times (95\%CI 1.080-1.057).

\section{DISCUSSION}

This study investigated the role of cognitive, emotional and sociodemographic variables as possible predictors of family function in caregivers of older spouses. The results showed that high levels of stress and depressive symptoms and presence of cognitive impairment predicted low levels of family function. Having a higher number of children predicted increased levels of family function.

The use of a cross-sectional design may not allow for drawing conclusions about whether such variables may predict family function over time. In addition, the use of a non-probabilistic sample may not allow for the generalization of the findings to the wider population of spousal caregivers. However, our findings can potentially help improve an understanding of the importance of developing and establishing health and social care policies for older caregivers aimed at improving family function and informal care management. It also contributes to the international literature around family caregiving in later life, which is currently lacking.

In the present study, a large proportion of our sample were women who reported adequate family function. Approximately 50\% scored lower than the expected overall median for the ACE-R, did not have depressive symptoms and perceived moderate to low stress levels. Previous studies report that caregivers, especially those of an individual with dementia or who experience a decline in cognitive performance or increase burden

Table 2. Multiple logistic regression investigating the predictors of family dysfunction in older spousal caregivers ( $\mathrm{n=298)}$ ), São Carlos, SP, Brazil, 2014.

\begin{tabular}{lccc}
\hline & OR & p-value & 95\%CI \\
\hline Perceived stress & -0.955 & 0.045 & $0.914-0.999$ \\
\hline Cognitive impairment & -0.160 & 0.005 & $0.444-0.579$ \\
\hline Depressive symptoms & -0.848 & 0.039 & $0.726-0.992$ \\
\hline Number of children (continuous) & 1.276 & 0.004 & $1.080-1.057$ \\
\hline
\end{tabular}

OR: Odds Ratio; 95\%Cl: 95\% confidence interval. and care-related stress. ${ }^{36-38}$ For family functionality, the values found in the present study with the Family Apgar instrument were in line with what was found with elderly people in the interior of São Paulo ${ }^{39}$ and Chile. ${ }^{40}$

This is important because women also often receive low levels of support, have more physical impairment, have lower income, and experience higher levels of stress and burden. ${ }^{41}$ Previous studies attempting to explain the relationships between the variables investigated in this study and family function in family caregivers are somewhat limited, but there is evidence suggesting a potential bidirectional relationship between family function and psychological well-being in older adults. For example, a study carried out with 304 North Korean adults with high risk for depression found that family function and resilience were predictors for the development of depressive symptoms; ${ }^{42}$ however, no study that tried to explain this relationship with caregivers was found.

There is relative consensus in the literature that informal/family support network is very important for the mental health and cognition of older adults. ${ }^{16,43,44}$ A systematic review of 39 studies suggests a relationship between social activity and global cognition, overall executive functioning, working memory, visuospatial abilities and processing speed. In addition, benefits older adults' cognitive functioning and changes in the characteristics of social relationships could be a consequence of cognitive decline as opposed to a cause however. ${ }^{16}$ Previous studies have suggested that low frequency of interactions, small social network size, or negative experiences of social support predict more rapid cognitive decline. ${ }^{45,46}$

Previous Brazilian research conducted with older adults found that those experiencing family dysfunction were more likely to report the presence of depressive symptoms compared to those without such dysfunction. ${ }^{47}$ The current study demonstrated that such associations can be bidirectional, with better cognitive health and less depressive symptoms predicting better family function in older people who are caregivers. The interaction between family relationships and health is bidirectional, since the worsening of health status leads to a restriction of the social network, while a decrease in social networks, in a repeated and prospective way, predicts serious morbidities and mortality. ${ }^{48}$ This is important as it has been pointed out in previous studies that older people who are caregivers are more likely to report the presence of depressive symptoms and more cognitive impairment than older people who are not caregivers. ${ }^{38}$

During adult life, one of the partners may take more responsibility in the family day-to-day activities. In later life, this person may be in need of care and this dynamic may need to change with the other person taking over 
the family responsibilities. Such changes in the family dynamics often generate insecurity, anger, resentfulness, and guilt, which can lead to or increase family conflicts. ${ }^{49-51}$ When the number of children is higher and the existing social support network around the older caregiver is strong, the likelihood of such feelings arising is reduced, which in turn helps protect the family function and the well-being of the older adults involved in the caregiving dyad. ${ }^{52}$

The current study did not find significant associations between family function and other individual and care-related variables that have been considered relevant to the population of older caregivers in the literature. For example, previous studies have shown that high levels of perceived burden, stress and depression are prevalent in older caregivers ${ }^{53}$ and are often associated with poor education and longer hours providing care. ${ }^{49}$ These, consequently, have been associated with lower family function. ${ }^{51}$ This study presented clear associations of factors with dysfunctional family, which could mean that these findings were linked to the specific sample study and could not be assumed for a general population. This study can support the development of protocols in health units and home care programs to track family functionality and intrinsic and extrinsic care resources, training of professionals working with the elderly segment and the insertion of professionals trained in gerontology in health teams, the design of monitoring programs for caregivers as psychoeducational groups, gerontological services (day centres, caregiver community centres, expansion of home care programs in Brazil), and strengthening of social and family support networks, in addition to educational work on ageing and the realities of care in communities, as indicated in the Global Plan for Attention to Dementia established by the World Health Organization., with goals between 2017 and 2025, with the creation of dementia-friendly communities. ${ }^{54}$
Having fewer children and also high stress levels, depressive symptoms and cognitive impairment were found to be predictors of family dysfunction in a Brazilian sample of older spousal caregivers. Research and support services for family caregivers are limited in Brazil and are mostly focused on reducing burden and stress only. The current study results demonstrated the importance of maintaining the cognitive health and psychological well-being of older caregivers, as well as considering the family arrangements for support to promote better family function for these individuals.

Future research should focus on studying a larger prospective cohort of older caregivers to understand the long-term impact of such factors on the older caregivers' physical and mental health.

\section{ACKNOWLEDGMENTS}

We declare financial support from Conselho Nacional de Desenvolvimento Científico e Tecnológico (CNPq) [Grant No. 304068/2015-6] and Fundação de Amparo à Pesquisa do Estado de São Paulo (Grant No. 2017/04129-9).

Authors' contributions: SCIP: conception, planning, data interpretation and writing-review. AGB: data collection, analysis, interpretation, and writing. BML: conception, planning, data collection and writing-review. DO: writing-review. FSO: conception, planning, analysis, data interpretation and writing. FGM: conception, planning and writing. HROS: conception, planning and writing. NAO: data collection and writing. MSZ: conception, planning and writing-review. AASO: conception, planning and writing-review. ACO: conception, planning, data collection, analysis, data interpretation and writing.

\section{REFERENCES}

1. Miranda GM, Mendes AC, Silva AL. Population aging in Brazil: current and future social challenges and consequences. Rev Bras Geriatr Gerontol. 2016;19(3):507-19. https://doi.org/10.1590/1809-98232016019.150140

2. Anjos KF, Boery RN, Pereira R, Pedreira LC, Vilela AB, Santos VC, et al. Association between social support and quality of life of relative caregivers of elderly dependents. Cienc Saude Colet. 2015;20(5):1321-30. https:// doi.org/10.1590/1413-81232015205.14192014

3. Marcondes G. Arranjos domiciliares multigeracionais: perfil e aportes em domicílios compostos por avós e netos. An VII Congr la Asoc Latinoam Población e XX Encontro Nac Estud Popul. 2017;0(0):1-16.

4. Stamm M, Mioto RC. Família e cuidado: uma leitura para além do óbvio. Cienc Cuid Saude. 2003;2(2):161-8. https://doi.org/10.4025/cienccuidsaude.v2i2.5539

5. Mazza MM, Lefèvre F. Caretaking within the family: Social representation analysis of the relationship between the caretaker and the elderly. Rev Bras Crescimento Desenvolv Hum. 2005;15(1):1-10.
6. Bahremand M, Rai A, Alikhani M, Mohammadi S, Shahebrahimi K, Janjani $P$. Relationship between family functioning and mental health considering the mediating role of resiliency in type 2 diabetes mellitus patients. Glob J Health Sci. 2014;7(3):254-9. https://doi.org/10.5539/gjhs.v7n3p254

7. Lamb AE, Biesecker BB, Umstead KL, Muratori M, Biesecker LG, Erby $\mathrm{LH}$. Family functioning mediates adaptation in caregivers of individuals with Rett syndrome. Patient Educ Couns. 2016;99(11):1873-9. https:// doi.org/10.1016/j.pec.2016.06.018

8. Wang $\mathrm{Y}-\mathrm{H}$, Haslam M, Yu M, Ding J, Lu Q, Pan F. Family functioning, marital quality and social support in Chinese patients with epilepsy. Health Qual Life Outcomes. 2015;13(1):10. https://doi.org/10.1186/ s12955-015-0208-6

9. Bianchi M, Flesch LD, Alves EV, Batistoni SS, Neri AL. Zarit burden interview psychometric indicators applied in older people caregivers of other elderly. Rev Latino-Am Enfermagem. 2016;24:e2835. https://doi. org/10.1590/1518-8345.1379.2835 
10. del-Pino-Casado R, Frías-Osuna A, Palomino-Moral PA, Ruzafa-Martínez M, Ramos-Morcillo AJ. Social support and subjective burden in caregivers of adults and older adults: A meta-analysis. PLoS One. 2018;13(1):e0189874. https://doi.org/10.1371/journal.pone.0189874

11. Oliveira Souza EN, Luchesi BM, Inouye K, Pavarini SC. Stress and optimism of elderlies who are caregivers for elderlies and live with children. Rev Bras Enferm. 2017;70(4):697-703. https://doi.org/10.1590/0034-7167-2017-0088

12. Vera I, Lucchese R, Nakatani AY, Adoyama G, Bachion MM, Vila VS. Factors associated with family dysfunction among non-institutionalized older people. Texto Contexto - Enferm. 2015;24(2):494-504. https://doi. org/10.1590/0104-07072015001602014

13. Amonkar P, Mankar M, Thatkar P, Sawardekar P, Goel R, Anjenaya S. A comparative study of health status and quality of life of elderly people living in old age homes and within family setup in Raigad District, Maharashtra. Indian Community Med. 2018;43(1):10. https://doi.org/10.4103/ijcm.IJCM 301_16

14. Aguiar AC, Menezes TM, Camargo CL. Family arrangements with the elderly: contributory factors. Av Enferm. 2018;36(3):292-301. http://dx.doi. org/10.15446/av.enferm.v36n3.68425

15. Reis $\llcorner A$, Trad LA. Suporte familiar ao idoso com comprometimento da funcionalidade: a perspectiva da família. Rev Psicol Teor Prática. 2015;17(3):2841. https://doi.org/10.15348/1980-6906/psicologia.v17n3p28-41

16. Kelly ME, Duff H, Kelly S, Power JEM, Brennan S, Lawlor BA, et al. The impact of social activities, social networks, social support and social relationships on the cognitive functioning of healthy older adults: a systematic review. Syst Rev. 2017;6(1):259. https://doi.org/10.1186/s13643-017-0632-2

17. Chen Y, Hicks A, While AE. Loneliness and social support of older people in China: a systematic literature review. Health Soc Care Community. 2014;22(2):113-23. https://doi.org/10.1111/hsc.12051

18. Hsiao CY, Tsai YF. Factors of caregiver burden and family functioning among Taiwanese family caregivers living with schizophrenia. J Clin Nurs. 2015;24(11-12):1546-56. https://doi.org/10.1111/jocn.12745

19. Campos AC, Rezende GP, Ferreira EF, Vargas AM, Gonçalves LH. Family functioning of Brazilian elderly people living in community. Acta Paul Enferm. 2017;30(4):358-67. http://dx.doi.org/10.1590/19820194201700053

20. Nunes DP, Brito TR, Duarte YA, Lebrão ML. Caregivers of elderly and excessive tension associated to care: evidence of the Sabe Study. Rev Bras Epidemiol. 2019;21(Supl2):e180020. https://doi.org/10.1590/1980549720180020.supl.2

21. Brigola AG, Luchesi BM, Alexandre TS, Inouye K, Mioshi E, Pavarini SC. High burden and frailty: association with poor cognitive performance in older caregivers living in rural areas. Trends Psychiatry Psychother. 2017;39(4):257-63. https://doi.org/10.1590/2237-6089-2016-0085

22. Pinquart M, Sörensen S. Spouses, adult children, and children-in-law as caregivers of older adults: A meta-analytic comparison. Psychol Aging. 2011;26(1):1-14. https://doi.org/10.1037/a0021863

23. Lino VT, Pereira SR, Camacho LA, Ribeiro Filho ST, Buskman S. Cross cultural adaptation of the Independence in Activities of Daily Living Index (Katz Index). Cad Saude Publica. 2008,24(1):103-12. https://doi. org/10.1590/S0102-311X2008000100010

24. Santos RL, Virtuoso Junior JS. Reliability of the Brazilian version of the Scale of Instrumental. Rev Bras Promoção Saude. 2008;21(4):290-6.

25. Duarte YA. Família: rede de suporte ou fator estressor. A ótica de idosos e cuidadores familiares. São Paulo: EEUSP; 2001.

26. Smilkstein $\mathrm{G}$. The family APGAR: a proposal for a family function test and its use by physicians. J Fam Pract. 1978;6(6):1231-9.

27. Vera I, Lucchese R, Munari DB, Nakatani AYK. Using the family APGAR score to evaluate family relationships in the elderly: an integrative review. Rev Eletr Enf. 2014;16(1):199-210. https://doi.org/10.5216/ree.v16i1.22514

28. Mioshi E, Dawson K, Mitchell J, Arnold R, Hodges JR. The Addenbrooke's Cognitive Examination Revised (ACE-R): a brief cognitive test battery for dementia screening. Int J Geriatr Psychiatry. 2006;21(11):1078-85. https:// doi.org/10.1002/gps.1610

29. Mathuranath PS, Nestor PJ, Berrios GE, Rakowicz W, Hodges JR. A brief cognitive test battery to differentiate Alzheimer's disease and frontotemporal dementia. Neurology. 2000;55(11):1613-20. https://doi. org/10.1212/01.wnl.0000434309.85312.19

30. César KG, Yassuda MS, Porto FHG, Brucki SMD, Nitrini R. Addenbrooke's cognitive examination-revised: Normative and accuracy data for seniors with heterogeneous educational level in Brazil. Int Psychogeriatr. 2017;29(8):1345-53. https://doi.org/10.1017/S1041610217000734

31. Yesavage JA, Sheikh Jl. Geriatric Depression Scale (GDS): Recent evidence and development of a shorter version. Clin Gerontol. 1986;5(12):165-73. https://doi.org/10.1300/J018v05n01_09

32. Almeida OP, Almeida SA. Short versions of the Geriatric Depression Scale: A study of their validity for the diagnosis of a major depressive episode according to ICD-10 and DSM-IV. Int J Geriatr Psychiatry. 1999;14(10):858 65. https://doi.org/10.1002/(sici)1099-1166(199910)14:10<858::aid-gps35>3.0.co;2-8
33. Cohen S, Kamarck T, Mermelstein R. A global measure of perceived stress. J Health Soc Behav. 1983;24(4):385-96. https://doi.org/10.2307/2136404

34. Di Bernardi Luft C, de Oliveira Sanches S, Mazo GZ, Andrade A. Brazilian version of the Perceived Stress Scale: translation and validation for the elderly. Rev Saude Publica. 2007;41(4):606-15. https://doi.org/10.1590/ S0034-89102007000400015

35. Hosmer DW, Lemeshow S, Sturdivant RX. Applied logistic regression. 3. ed. New Jersey: John Wiley \& Sons; 2013. Wiley Series in Probability and Statistics). https://doi.org/10.1002/9781118548387

36. Dassel KB, Carr DC, Vitaliano P, Pruchno R. Does caring for a spouse with dementia accelerate cognitive decline? findings from the health and retirement study. Gerontologist. 2017;57(2):319-28. https://doi.org/10.1093/ geront/gnv148

37. Allen AP, Curran EA, Duggan Á, Cryan JF, Chorcoráin AN, Dinan TG, et al. A systematic review of the psychobiological burden of informal caregiving for patients with dementia: Focus on cognitive and biological markers of chronic stress. Neurosci Biobehav Rev. 2017;73:123-64. https://doi. org/10.1016/j.neubiorev.2016.12.006

38. O'Sullivan M, Brennan S, Lawlor BA, Hannigan C, Robertson IH, Pert MM. Cognitive functioning among cognitively intact dementia caregivers compared to matched self-selected and population controls. Aging Ment Health. 2019;23(5):566-73. https://doi.org/10.1080/136 07863.2018.1428937

39. dos Santos AA, Pavarini SCI, Barham EJ. Percepção de idosos pobres com alterações cognitivas sobre funcionalidade familiar. Texto Contexto - Enferm. 2011;20(1):102-10. http://dx.doi.org/10.1590/S010407072011000100012

40. Zavala G. M, Vidal G. D, Castro S. M, Quiroga P, Klassen P. G. Funcionamiento social del adulto mayor. Cienc Enferm. 2006;12(2):53-62. https:// doi.org/10.4067/S0717-95532006000200007

41. Shahly V, Chatterji S, Gruber MJ, Hamzawi AA, Alonso J, Andrade LH et al. Cross-national differences in the prevalence and correlates of burden among older family caregivers in the World Health Organization World Mental Health (WMH) Surveys. Psychol Med. 2013;43(4):865-79. https:// doi.org/10.1017/S0033291712001468

42. Nam B, Kim JY, DeVylder JE, Song A. Family functioning, resilience, and depression among North Korean refugees. Psychiatry Res. 2016;245:451 7. https://doi.org/10.1016/j.psychres.2016.08.063

43. Tajvar M, Fletcher A, Grundy E, Arab M. Social support and health of older people in Middle Eastern countries: A systematic review. Australas J Ageing. 2013;32(2):71-8. https://doi.org/10.1111/j. 1741-6612.2012.00639.x

44. Rabelo DF, Neri AL. Avaliação das relações familiares por idosos com diferentes condições sociodemográficas e de saúde. Psico-USF. 2016;21(3):663-75. http://dx.doi.org/10.1590/1413-82712016210318

45. Lara E, Caballero FF, Rico-Uribe LA, Olaya B, Haro JM, Ayuso-Mateos $\mathrm{JL}$, et al. Are loneliness and social isolation associated with cognitive decline? Int J Geriatr Psychiatry. 2019;34(11):1613-22. https://doi. org/10.1002/gps.5174

46. Kuiper JS, Zuidersma M, Zuidema SU, Burgerhof JG, Stolk RP, Voshaar $\mathrm{RC}$, et al. Social relationships and cognitive decline: a systematic review and meta-analysis of longitudinal cohort studies. Int J Epidemiol. 2016;45(4):1169-206. https://doi.org/10.1093/ije/dyw089

47. Souza RA, Costa GD, Yamashita CH, Amendola F, Gaspar JC, Alvarenga $\mathrm{MR}$, et al. Family functioning of elderly with depressive symptoms. Rev Esc Enferm USP. 2014;48(3):469-76. https://doi.org/10.1590/S0080623420140000300012

48. Cerhan JR, Wallace RB. Predictors of decline in social relationships in the rural elderly. Am J Epidemiol. 1993;137(8):870-80. https://doi. org/10.1093/oxfordjournals.aje.a116748

49. Oliveira DC, D'Elboux MJ. National studies on family caregivers of older persons: integrative review. Rev Bras Enferm. 2012;65(5):829-38. https:// doi.org/10.1590/S0034-71672012000500017

50. Santos-Orlandi AA, Brito TRP, Ottaviani AC, Rossetti ES, Zazzetta MS, Gratão AC, et al. Profile of older adults caring for other older adults in contexts of high social vulnerability. Esc Anna Nery. 2017;21(1):1-8. https://doi.org/10.5935/1414-8145.20170013

51. Reis LA, Reis LA, Torres GV, Santos KT. Influência da dinâmica familiar Rev Pesqui em Fisioter. 2014;4(2):123-30. http://dx.doi.org/10.17267/ 2238-2704rpf.v4i2.399

52. Santos AA, Pavarini SCl. Family functionality regarding the elderly with cognitive impairments: The caretaker's perception. Rev Esc Enferm USP. 2012;46(5):1141-7. https://doi.org/10.1590/S008062342012000500015

53. Aguiar ES, Pimentel I, Fernandes MG, Silva AO. Representações sociais do cuidar de idosos para cuidadores: revisão integrativa. Rev Enferm UERJ. 2011;19(3):485-90.

54. World Health Organization. Global Action Plan on the Public Health Response to Dementia 2017-2025. Geneva: WHO; 2017. 